\title{
The fate of bacterial carbon in an intertidal sediment: Modeling an in situ isotope tracer experiment
}

\author{
Dick van Oevelen, Jack J. Middelburg, Karline Soetaert, and Leon Moodley
}

Netherlands Institute of Ecology (NIOO-KNAW), Centre for Estuarine and Marine Ecology, Korringaweg 7, 4401 NT Yerseke, The Netherlands

\begin{abstract}
We report the results of an integrated modeling and in situ isotope tracer experiment study examining the fate of bacterial carbon in an intertidal sediment. ${ }^{13} \mathrm{C}$-glucose was injected into the upper $10 \mathrm{~cm}$ of an intertidal sediment, which successfully tagged the bacterial community as evidenced by ${ }^{13} \mathrm{C}$ enrichment of bacterial specific polar-lipid-derived fatty acids. Over a period of 4.5 months, ${ }^{13} \mathrm{C}$ enrichment was monitored in sediment organic carbon, bacteria, meiobenthos, macrobenthos, and dissolved inorganic carbon. A mechanistic model accurately simulated label transfer among the biotic and abiotic compartments and was used to derive bacterial production and the loss processes grazing, mortality, respiration, and exchange. Bacterial production averaged $67 \mathrm{mmol} \mathrm{C} \mathrm{m} \mathrm{C}^{-2} \mathrm{~d}^{-1}$, of which $8 \%$ was lost from the sediment by exchange processes, $3 \%$ was grazed by meiobenthos and $24 \%$ by macrobenthos. The primary fate of bacterial production was mortality $(65 \%)$ and the released bacterial carbon was recycled back to dissolved organic carbon, resulting in recycling of carbon within the dissolved organic carbon-bacteria loop. Bacterial respiration was the main loss process from this loop. Although a significant fraction of bacterial carbon production was grazed, our results show that bacterial carbon is primarily a sink of organic carbon in the food web of intertidal sediments.
\end{abstract}

Biogeochemical cycling in organic matter rich coastal and intertidal sediments is dominated by heterotrophic bacterial communities. Although being highly diverse in terms of species and metabolic strategies (Fenchel et al. 1998), total bacterial numbers in the surface layers of these sediments are comparatively constant at around $10^{9}$ bacteria $\mathrm{cm}^{-3}$ pore water (Schallenberg and Kalff 1993; Schmidt et al. 1998). Irrespective of this constancy, specific growth rates vary by four orders of magnitude across freshwater and marine sediments (Sander and Kalff 1993). The importance of bacteria in early diagenetic processes and their potential as food source has generated ample interest in the processes affecting sedimentary bacterial carbon and is approached from at least three directions: (1) bottom-up control, (2) biogeochemical approach, and (3) top-down control.

The bottom-up approach has focused on finding linear relationships between particulate organic matter and bacterial biomass or production. These relationships may be spurious for various reasons (Bird and Duarte 1989), but when standardized to volumetric units, significant relationships explain $25-60 \%$ of the observed variation in bacterial biomass (Schallenberg and Kalff 1993) and production

\footnotetext{
Acknowledgments

Cynthia van der Voorn, Ria Bos, Pieter van Rijswijk, Maria Andersson, Wil Sistermans, Gert Weststrate, Ko Verschuure, and Anton Tramper are gratefully acknowledged for their skillful assistance during various stages of the field and laboratory work. Bart Veuger, Filip Meysman, Eric Boschker, Peter Herman, and Carlo Heip provided stimulating feedback during the elaboration and writing stage. One anonymous reviewer and Pete Jumars are thanked for their constructive comments. This research was partially supported by the Netherlands Organization of Scientific Research (PIONIER 833.02.2002 and VLANEZO 832.11.011). This is publication 3744 of the Netherlands Institute of Ecology (NIOO-KNAW), Yerseke.
}

(Sander and Kalff 1993), suggesting that substrate availability impacts bacterial dynamics.

Biogeochemists usually focus on hydrolysis rates of standardized substrates or sediment-dissolved organic matter (Arnosti and Holmer 1999), production of bacterial biomass, and bacterial growth efficiency (del Giorgio and Cole 1998). Hence, the biogeochemical approach resolves rates of oxic, suboxic, and anoxic mineralization pathways, but the fate of bacterial production is not explicitly studied.

In the top-down approach, bacterial carbon is assumed to be regulated by higher trophic levels of the benthic food web, a topic that has a long-standing interest dating back to the 1930s (ZoBell 1938). In a seminal review on bacterivory in coastal and intertidal sediments, Kemp (1990) asserted that bacteria do not form an important constituent of the macrobenthic diet and revealed that reports for meiobenthos (mostly nematodes) were conflicting. It was, however, noted that quantitative data on grazing by meiobenthos and protozoans were either sparse or lacking. Methodological advances have been made, such as the use of fluorescent-stained sediment (Starink et al. 1994) and radioactively labeled substrates (Montagna 1993). Using these methods, quantitative data on bacterivory by smallsized grazers have been gathered (Epstein and Shiaris 1992; Hamels et al. 2001). In general, only $1-20 \%$ of the bacterial production is observed to be grazed, although grazing intensity may fluctuate seasonally (Hamels et al. 2001). Grazing studies are generally focused on the top centimeter of the sediment and are based on comparatively short time incubations (minutes to hours) in retrieved and/or slurried sediments, rendering translation to the field and longer periods cumbersome. In addition, bacterial production measurements suffer similar limitations (Kemp 1990) and data are obtained by other methods than bacterivory and therefore do not form an integral part of the grazing studies. 
Another top-down agent that has received interest is viral infection (Paul et al. 1993; Fischer et al. 2003), which potentially exerts control on bacteria through infection and subsequent cell lysis. This mechanism may set upper limits on bacterial biomass or production but leaves unexplained the subsequent fate of the bacterially derived carbon. Studies carried out in continental margin sediments show burial of recalcitrant bacterial cell wall remnants (Grutters et al. 2002). However, Novitsky (1986) reported rapid mineralization of dead microbial biomass in a tropical marine beach sediment.

It is clear that several regulating factors act on sedimentary bacteria and a comprehensive understanding calls for the integration of bottom-up, biogeochemical, and top-down approaches. Boudreau (1999) provided such an integration by developing spatial and temporal mass balance equations of bacterial carbon in sediments and used these in a theoretical investigation to explain the observed linear relationship between bacterial biomass and sediment particulate organic carbon (POC). The parameters of this linear relationship are nonlinear composites of parameters describing exchange processes, bacterial growth efficiency, and biological processes, including growth, mortality, and grazing.

We report the results of a ${ }^{13} \mathrm{C}$-glucose labeling experiment and use the data in a mechanistic model to quantify the fate of sedimentary bacterial carbon production in an intertidal sediment. ${ }^{13} \mathrm{C}$-glucose was injected into the surface $10 \mathrm{~cm}$ of an intertidal sediment and traced into bacterial specific polar-lipid-derived fatty acids (PLFA), total organic carbon, meiobenthos, macrobenthos, and respired carbon during a period of 4.5 months. The modeled processes were selected based on the comprehensive analysis by Boudreau (1999). The combined modeling $-{ }^{13} \mathrm{C}$ isotope tracer study allowed us to quantify bacterial production, bacterial growth efficiency, mortality, exchange, and bacterial grazing.

\section{Materials and methods}

Experimental approach-The Molenplaat intertidal flat was chosen as the study site because detailed physical and biological background data are available (Middelburg et al. 2000 and references therein). The intertidal flat is located in the saline part (salinity 20-25) of the turbid, heterotrophic, and nutrient-rich Scheldt estuary. The sampling site is located at the muddy center of the flat $\left(51^{\circ} 26.25^{\prime} \mathrm{N}\right.$, $3^{\circ} 57.11^{\prime} \mathrm{E}$ ), has a median grain size of $77 \mu \mathrm{m}$, organic carbon content of $0.5 \mathrm{wt} \%$, exposure time of about $7 \mathrm{~h}$ per tidal cycle, and a sediment oxygen consumption of $176 \mathrm{mmol} \mathrm{C} \mathrm{m}^{-2} \mathrm{~d}^{-1}$.

Our intention was to specifically label the bacterial community within a period of days. To minimize direct transfer of the ${ }^{13} \mathrm{C}$ source to meiobenthos and macrobenthos, we opted for a labile dissolved organic carbon source and chose glucose for several reasons. Previous experiments have shown that glucose resulted in labeling of a broad spectrum of different PLFAs, indicating that glucose is a universal substrate for the bacterial community
(Boschker, pers. comm.). Moreover, glucose is a comparatively cost-efficient substrate.

Prior to labeling, two $0.25-\mathrm{m}^{2}$ metal frames $(0.5 \times 0.5 \times$ $0.08 \mathrm{~m}$ ) were inserted in the sediment. On 21 May 2003, the upper $10 \mathrm{~cm}$ was labeled in $2 \mathrm{~h}$ by injecting $0.4 \mathrm{~mL}{ }^{13} \mathrm{C}$ glucose solution $\left(23.5 \mathrm{mmol}{ }^{13} \mathrm{C} \mathrm{L}^{-1}\right)$ into four hundred $6.25-\mathrm{cm}^{2}$ squares, which resulted in a flux of $15.3 \mathrm{mmol}{ }^{13} \mathrm{C}$ $\mathrm{m}^{-2}$ per labeling day. The ${ }^{13} \mathrm{C}$-glucose solution was syringe injected by inserting the needle $10 \mathrm{~cm}$ deep and gradually emptying the syringe during retraction from the sediment to achieve a uniform depth distribution of the ${ }^{13} \mathrm{C}$-glucose solution. Labeling was performed daily for 5 consecutive $\mathrm{d}$ to ensure sufficient label incorporation by bacteria, but labeling on day 2 had to be canceled due to bad weather. Sampling frequency was high initially (days $0,0.2,2,3,4,5$, $6,8,12,18$ ) and lower thereafter (days $36,71,136$ ). On each sampling day, one sampling core was taken per plot. Sampling positions within the plots were determined a priori by a randomization procedure. A sampling core (inner diameter [i.d.] $5 \mathrm{~cm}$ ) was inserted $10 \mathrm{~cm}$ deep, filled with filtered seawater, and closed with a gas-impermeable rubber stopper. A metal core (i.d. $9 \mathrm{~cm}$ ) was inserted around the sampling core to prevent disturbance of the plot and remained in place during the experiment. The sampling cores were transported to the laboratory in a dark, cool container. Filtered seawater was used to fill the sampling core. The ${ }^{13} \mathrm{C}$ dissolved inorganic carbon (DIC) that accumulated in the overlying water between field sampling and laboratory processing was used to quantify the ${ }^{13} \mathrm{C}$ DIC flux during submerged conditions. The measured ${ }^{13} \mathrm{C}-$ DIC flux was used to calculate the daily ${ }^{13} \mathrm{C}$ respiration by extrapolating from the incubation time to $24 \mathrm{~h}$. Upon arrival in the laboratory, the sediment cores were sliced into three depth intervals $(0-2 \mathrm{~cm}, 2-5 \mathrm{~cm}$, and 5-10 cm), homogenized, and sampled for total organic carbon (TOC), ${ }^{13}$ C-TOC, PLFA, and ${ }^{13}$ C-PLFA $(5-10 \mathrm{~mL}$ wet sediment), porewater DIC, and ${ }^{13} \mathrm{C}$-DIC $(15-20 \mathrm{~mL}$ wet sediment), meiobenthic biomass, and label incorporation (10 mL wet sediment). The remaining sediment $(\sim 15 \mathrm{~mL}$ for $0-2 \mathrm{~cm}, \sim 35 \mathrm{~mL}$ for $2-5 \mathrm{~cm}$, and $\sim 75 \mathrm{~mL}$ for $5-10 \mathrm{~cm}$ ) was used to measure label incorporation by macrobenthos. Meiobenthic and macrobenthic samples were fixed with formalin (final concentration 4\%). In this article, we will present total uptake by meiobenthos and macrobenthos, while uptake rates of meiobenthic groups and macrobenthic species will be presented in an article that focuses on the importance of bacterial carbon in their diets (Van Oevelen et al., unpubl. data).

Analytical procedures - Sediment samples were weighed, freeze-dried, weighed again, and converted to porosity assuming a dry sediment density of $2.55 \mathrm{~g} \mathrm{~cm}^{-3}$. Organic carbon content and stable isotope ratios of sediment TOC, meiobenthos, and macrobenthos were measured by elemental analyzer-isotope ratio mass spectrometry (EAIRMS) (Middelburg et al. 2000). Label incorporation by bacteria was calculated from incorporation into specific bacterial PLFA biomarkers. Lipids were extracted from $3 \mathrm{~g}$ dry sediment using a Bligh and Dyer extraction, from which the PLFA fraction was isolated by sequentially 
rinsing the lipid extract on a silicic acid column with chloroform, acetone, and methanol. The PLFA extract was derivatized to volatile fatty acid methyl esters (FAME) and measured by gas chromatography-isotope ratio mass spectroscopy (GC-IRMS) for PLFA concentration and $\delta^{13}$ C-PLFA (Middelburg et al. 2000). PLFAs are present in bacterial membranes and comprise roughly $6 \%$ of the total carbon in a bacterial cell. The bacterial-specific PLFAs (i14:0, i15:0, a15:0, i16:0, and 18:1 $\omega 7 \mathrm{c}$ ) together account for $28 \%$ of the carbon in total bacterial PLFAs. These conversion factors have been used to convert PLFA concentrations to bacterial biomass and label incorporation in PLFAs to total bacterial label incorporation (Middelburg et al. 2000).

Pore water was extracted by centrifugation and transferred to a helium-flushed headspace vial, acidified $(0.1 \mathrm{~mL}$ $\mathrm{H}_{3} \mathrm{PO}_{4} \mathrm{~mL}^{-1}$ pore water), and stored upside down. A 3-mL headspace was created in the DIC/13C-DIC water samples, which were taken from the overlying water in the sampling core, by replacing water with He and acidifying the water sample as described above. DIC and ${ }^{13} \mathrm{C}$-DIC were determined by EA-IRMS (Moodley et al. 2000).

The meiobenthos, retained on a $38-\mu \mathrm{m}$ sieve, included permanent (Nematoda, hard-shelled Foraminifera, softbodied Foraminifera, Turbellaria, and Copepoda) and temporary (juveniles Heteromastus filiformis and small Polycheata) meiobenthic groups. The first 15-30 encountered specimens of each individual meiobenthic group were handpicked from a known sample split for isotope analysis. The remainder of the sample split was quantified for total densities. Specimens collected for isotope analysis were cleaned of adhering detritus, rinsed (0.2- $\mu \mathrm{m}$ filtered water), transferred to silver boats, and stored frozen. Prior to isotope analysis, the samples were thawed, acidified for carbonate removal with $20 \mu \mathrm{L} 2.5 \% \mathrm{HCl}$, oven-dried $\left(50^{\circ} \mathrm{C}\right)$, and pinched closed. Meiobenthic biomass was estimated directly from the carbon content of individual specimens (determined from the carbon signal from the EA-IRMS, calibrated with $\mathrm{Cs}_{2} \mathrm{CO}_{3}$ standards) and multiplied by the number of organisms in the sample split. Processing the meiobenthic samples proved to be very time consuming and some sacrifices were made: stable isotope data are based on samples from plot 2 only and the biomass is estimated from the samples taken at days $0,0.2,2,4$, and 6 .

All macrobenthic specimens were handpicked from the sample, stored in filtered water, and preserved with formalin. The sorted sample was transferred to a Petri dish, from which a species sample was taken, rinsed, transferred to a silver boat, and stored frozen. Bivalves were placed in an acidified bath $(1 \mathrm{mmol} \mathrm{HCl})$ to dissolve the carbonate shell, cleaned of debris, rinsed thoroughly, and either whole specimens (small specimens) or flesh samples (large specimens) were transferred to silver boats and stored frozen. Sample treatment prior to isotope analysis was similar to that of the meiobenthic samples. Macrobenthic biomass could not be accurately determined from the small sampling cores but instead was determined during a dedicated sampling on 27 May 2003: 12 cores (i.d. $10 \mathrm{~cm}$ ) were taken close to the experimental plots, sliced into $0-2,2-5,5-10,10-20$, and $>20 \mathrm{~cm}$ intervals, fixed with formalin (4\% final concentration), sieved (1 mm), sorted, weighed for wet weight, and finally converted to C units using species-specific conversion factors available from a large database at the Netherlands Institute of Ecology (http://www.monitortaskforce.com).

Delta values are expressed relative to the carbon isotope ratio $\left(R={ }^{13} \mathrm{C} /{ }^{12} \mathrm{C}\right)$ of Vienna Pee Dee Belemnite (VPDB): $\delta^{13} \mathrm{C}(\%)=\left(R_{\text {sample }} / R_{V P D B}-1\right) \times 1000, R_{V P D B}$ is 0.0112372 . Label incorporation $(I)$ is presented as total label content in $\mathrm{mmol}^{13} \mathrm{C} \mathrm{m}^{-2}$ in the top $10 \mathrm{~cm}$, where $I$ is calculated as $\left(F_{\text {sample }}-F_{\text {background }}\right) \times S$, where $F$ is the ${ }^{13} \mathrm{C}$ fraction $\left({ }^{13} \mathrm{C} /\left({ }^{13} \mathrm{C}+{ }^{12} \mathrm{C}\right)=R /(R+1)\right)$ and $S$ is the total carbon stock (mmol C m${ }^{-2}$ ) of the respective compartment.

All total carbon and ${ }^{13} \mathrm{C}$ data reported are integrated over the top $10 \mathrm{~cm}$ of the sediment.

Model description-A mechanistic model was used to simulate the transfer of label among the biotic and abiotic compartments. The model structure was inspired by the bacterial mass balance description of Boudreau (1999), but was assumed to be zero dimensional as the incorporated processes did not require more complexity. POC, dissolved organic carbon (DOC), and bacterial carbon dynamics are implemented as $\mathrm{C}$ and excess ${ }^{13} \mathrm{C}$ balances, whereas meiobenthos and macrobenthos are modeled only as excess ${ }^{13} \mathrm{C}$ under the assumption that their total biomass is at steady state (Fig. 1). All model variables are listed in Table 1, model parameters are in Table 2, and model equations of state variables (s\#) and variables $(\mathrm{v} \#)$ are in Table 3.

The biological processes are influenced by temperature using the $Q_{10}$ formulation (v1). Carbon input to POC is constant (v2), but ${ }^{13} \mathrm{C}$-glucose injection occurs in a period of $2 \mathrm{~h}$ (v4). POC dissolution (v5) and uptake of DOC by bacteria (v8) are first-order processes, which is conceptually equivalent to the common formulation in diagenetic models (Boudreau 1999). Adsorption of a part of the injected glucose (v3) occurs immediately after amendment (Henrichs and Sugai 1993). A fixed fraction of the DOC uptake by bacteria is respired and the remainder is incorporated into bacterial biomass (s3, s9). Bacterial mortality is a firstorder process (v6) and the bacterially derived organic carbon flows to DOC (s2). Exchange processes are a dilution term acting on ${ }^{13} \mathrm{C}-\mathrm{POC}$ (e.g., advection, resuspension), ${ }^{13} \mathrm{C}-\mathrm{DOC}$ (e.g., diffusion, bioirrigation), and ${ }^{13}$ C-bacteria (e.g., advection, resuspension) (v11), under the assumption that exchanged labeled carbon is replaced by unlabeled carbon. Most organic matter and bacteria are attached to sediment grains; therefore, the exchange rate for POC and bacteria is taken as equal (v11). Meiobenthic and macrobenthic biomass are assumed to be in steady state. Their biomass, PB (production : biomass) ratio, and growth efficiency generate a carbon demand (v12), which is fulfilled partly by DOC (v9) and bacteria (v10). The steady-state assumption implies that secondary production by meiobenthos and macrobenthos is balanced by loss processes, such as mortality or grazing by higher trophic levels (e.g., fish and birds). In the model, meiobenthos and macrobenthos consist of two compartments: a metabolic and a structural compartment. All assimilated carbon enters the metabolic compartment; 


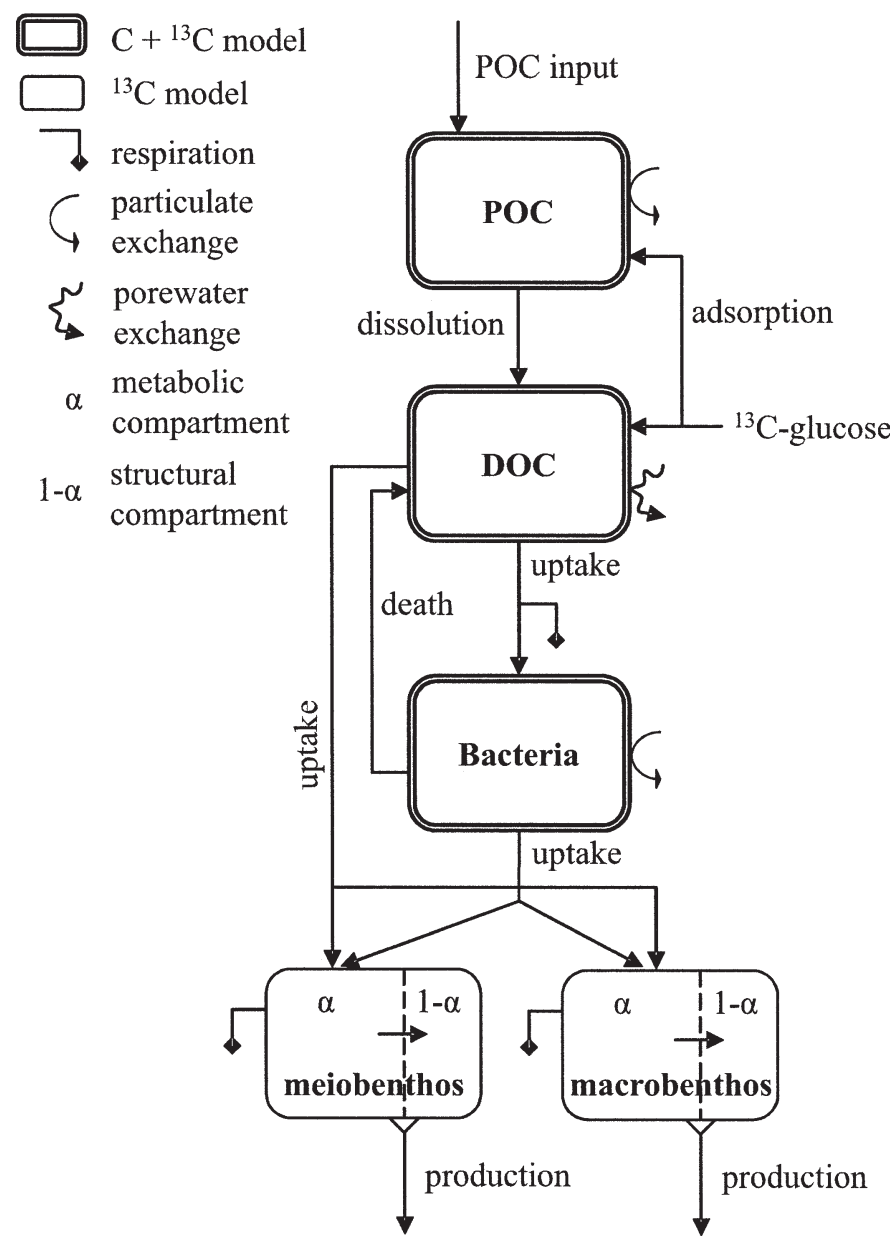

Fig. 1. Schematic of the model showing the carbon pathways among particulate organic carbon (POC), dissolved organic carbon (DOC), bacteria, meiobenthos, and macrobenthos.

turnover of this compartment is due to respiration and production (s7). A continuous flow feeds the structural compartment, of which the turnover is solely due to production (s8).

The model was implemented in the modeling environment FEMME (Soetaert et al. 2002), the environment and model code can be downloaded from http://www.nioo. knaw.nl/ceme/femme. The model was solved with a fourthorder Runge-Kutta integration method with a fixed time step of $0.01 \mathrm{~d}$. A spin-up period of $300 \mathrm{~d}$ successfully damped the effect of initial conditions.

Calibration and uncertainty analysis-For most model parameters, a range of possible parameter values was determined from literature reports (Table 2). The set of parameter values that optimally reproduced the observations was selected from these ranges. The selection was based on minimization of a weighted cost function,

$$
J=\sum_{i=1}^{N \operatorname{Var}} \sum_{j=1}^{N O b s} \frac{\left(M_{i j}-O_{i j}\right)^{2}}{\sigma_{i}^{2}}
$$

in which all deviations (NObs) of model $\left(M_{i j}\right)$ versus observation $\left(O_{i j}\right)$ are squared and weighed by the variance $\sigma_{i}^{2}$ for all variables (NVar). The $\sigma_{i}$ is the average standard deviation for each variable. This cost function quantifies the model - data misfit and the optimal fit was found by minimizing the cost function.

The available data on total carbon pools are from bacterial carbon and TOC, and these show significant variation over the season, and when the model is fitted to these data, this variation dominates the cost function. The first-order model described here is suitable to track exponential-like tracer kinetics, but is inappropriate to model short-term temporal and spatial variation. To alleviate the impact of varying bacterial and TOC pools on the cost function, the season-averaged pool size and variance have been evaluated in the cost function instead of the original data (see also Discussion). This ensures a correct order-of-magnitude pool size, but moderates the impact on the cost function. A pseudorandom calibration method (25,000 runs and population size 500) was chosen because of its ability to locate the global minimum in a large parameter space (Price 1979). The calibration ended with 250 runs of the Levenberg-Marquardt gradient method because of its ability to quickly converge to the minimum, once in a valley.

Parameter uncertainty, induced by fitting a model to uncertain data, was estimated by Bayesian inference (Gelman et al. 2003), using a Markov chain Monte Carlo technique. The Markov chain was initiated with the best-fit solution resulting from the calibration; it was terminated when 2,000 draws were selected. The mean and standard deviation of the model parameters were calculated from the selected draws.

\section{Results}

Organic carbon pools-Sediment TOC averaged 0.48 $\mathrm{wt} \%$ and porosity was 0.50 , giving a TOC pool of $46.6 \mathrm{~mol} \mathrm{C} \mathrm{m}^{-2}$ in the upper $10 \mathrm{~cm}$ of the sediment. The benthic community was dominated by macrobenthos $\left(1,624 \mathrm{mmol} \mathrm{C} \mathrm{m}{ }^{-2}\right)$, followed by bacteria $(781 \mathrm{mmol}$ $\mathrm{C} \mathrm{m}^{-2}$ ) and meiobenthos (188 $\mathrm{mmol} \mathrm{C} \mathrm{m}^{-2}$ ) (Table 4). Meiobenthic biomass was dominated by nematodes and foraminifera. Macrobenthos was dominated by large specimens of the bivalve Macoma balthica and the polychaetes Heteromastus filiformis and Pygospio elegans.

Label trajectories and model fits-The excess ${ }^{13} \mathrm{C}$ in the TOC pool, comprising excess ${ }^{13} \mathrm{C}$ in $\mathrm{POC}, \mathrm{DOC}$, and benthos, was very comparable among the two plots over the entire experimental period (Fig. 2A). Excess ${ }^{13} \mathrm{C}$-TOC increased steadily during the labeling period (except for the dip at day 2 caused by the canceled injection) and peaked at the end of the labeling period at around $25 \mathrm{mmol}^{13} \mathrm{C} \mathrm{m}^{-2}$. At day 5, 52\% of the total injected $61.1 \mathrm{mmol}^{13} \mathrm{C} \mathrm{m}^{-2}$ was recovered as excess ${ }^{13} \mathrm{C}$-TOC $(44 \%)$ and respired ${ }^{13} \mathrm{C}$-DIC $(8 \%)$. The initial ${ }^{13} \mathrm{C}$-TOC decrease was high, but slowed after day 20, reflecting turnover differences of the different organic carbon pools. After 4.5 months, almost no excess ${ }^{13} \mathrm{C}$ was detected in the 
Table 1. Model state variables, variables, and forcing functions. The symbol $X$ has a variable interpretation, which is detailed in the description.

\begin{tabular}{|c|c|c|}
\hline State variable & Unit & Description \\
\hline$P$ & $\mathrm{mmol} \mathrm{C} \mathrm{m}{ }^{-2}$ & Particulate organic carbon concentration (POC) \\
\hline$D$ & $\mathrm{mmol} \mathrm{C} \mathrm{m}{ }^{-2}$ & Dissolved organic carbon concentration (DOC) \\
\hline$B$ & $\mathrm{mmol} \mathrm{C} \mathrm{m}-2$ & Bacterial biomass \\
\hline$P_{13 C}$ & $\mathrm{mmol}{ }^{13} \mathrm{C} \mathrm{m}^{-2}$ & Excess ${ }^{13} \mathrm{C}$ in $\mathrm{POC}$ \\
\hline$D_{13 C}$ & $\mathrm{mmol}{ }^{13} \mathrm{C} \mathrm{m}^{-2}$ & Excess ${ }^{13} \mathrm{C}$ in $\mathrm{DOC}$ \\
\hline$B_{13 C}$ & $\mathrm{mmol}{ }^{13} \mathrm{C} \mathrm{m}^{-2}$ & Excess ${ }^{13} \mathrm{C}$ in bacterial biomass \\
\hline$M x E_{13 C}$ & $\mathrm{mmol}{ }^{13} \mathrm{C} \mathrm{m}^{-2}$ & Excess ${ }^{13} \mathrm{C}$ in metabolic mass of meiobenthos or macrobenthos \\
\hline$M x S_{13 C}$ & $\mathrm{mmol}{ }^{13} \mathrm{C} \mathrm{m}^{-2}$ & Excess ${ }^{13} \mathrm{C}$ in structural mass of meiobenthos or macrobenthos \\
\hline$D I C_{13 C}$ & $\mathrm{mmol}{ }^{13} \mathrm{C} \mathrm{m}^{-2}$ & Respired excess ${ }^{13} \mathrm{C}$, accumulated in time \\
\hline Variable & Unit & Description \\
\hline$F_{x}$ & ${ }^{13} \mathrm{C} / \mathrm{C}$ & Fraction ${ }^{13} \mathrm{C}$ of total $\mathrm{C}$ in compartment $x$ \\
\hline$f(T)$ & - & Temperature effect \\
\hline$M e_{13 C}$ & $\mathrm{mmol}{ }^{13} \mathrm{C} \mathrm{m}^{-2}$ & Excess ${ }^{13} \mathrm{C}$ in meiobenthos \\
\hline$M a_{13 C}$ & $\mathrm{mmol}{ }^{13} \mathrm{C} \mathrm{m}^{-2}$ & Excess ${ }^{13} \mathrm{C}$ in macrobenthos \\
\hline Org & $\mathrm{mmol} \mathrm{C} \mathrm{m}{ }^{-2}$ & Sum of $P, D, B, M e$, and $M a$ \\
\hline $\operatorname{Org}_{13 C}$ & $\mathrm{mmol}{ }^{13} \mathrm{C} \mathrm{m}^{-2}$ & Sum of $P_{13 C}, D_{13 C}, B_{13 C}, M e_{13 C}$, and $M a_{13 C}$ \\
\hline $\operatorname{dis} P_{P, D}$ & $\mathrm{mmol} \mathrm{C} \mathrm{m}{ }^{-2} \mathrm{~d}^{-1}$ & Dissolution of POC \\
\hline adsGlu $u_{G l u, P}$ & $\mathrm{mmol}^{13} \mathrm{C} \mathrm{m}^{-2} \mathrm{~d}^{-1}$ & Injected glucose adsorbed to POC \\
\hline $\operatorname{dis} \mathrm{lu}_{G l u, D}$ & $\mathrm{mmol}{ }^{13} \mathrm{C} \mathrm{m}^{-2} \mathrm{~d}^{-1}$ & Injected glucose dissolved as DOC \\
\hline upt $D_{D, B}$ & $\mathrm{mmol} \mathrm{C} \mathrm{m}{ }^{-2} \mathrm{~d}^{-1}$ & Uptake of DOC by bacteria \\
\hline $\operatorname{mor} B_{B, D}$ & $\mathrm{mmol} \mathrm{C} \mathrm{m}{ }^{-2} \mathrm{~d}^{-1}$ & Bacterial mortality \\
\hline $\operatorname{graM}_{B, M}$ & $\mathrm{mmol} \mathrm{C} \mathrm{m}-2 \mathrm{~d}^{-1}$ & Bacterial grazing by meiobenthos and macrobenthos \\
\hline $\operatorname{sor} M_{D, M}$ & $\mathrm{mmol} \mathrm{C} \mathrm{m} \mathrm{C}^{-2} \mathrm{~d}^{-1}$ & DOC uptake by meiobenthos and macrobenthos \\
\hline proMx & $\mathrm{mmol} \mathrm{C} \mathrm{m} \mathrm{m}^{-2} \mathrm{~d}^{-1}$ & Production by meiobenthos $(M e)$ or macrobenthos $(M a)$ \\
\hline $\operatorname{exc} X$ & $\mathrm{mmol}^{13} \mathrm{C} \mathrm{m}^{-2} \mathrm{~d}^{-1}$ & Exchanges of excess ${ }^{13} \mathrm{C}$-POC, ${ }^{13} \mathrm{C}$-DOC, or ${ }^{13} \mathrm{C}$-bacteria \\
\hline Forcing & Unit & Description \\
\hline Temp & ${ }^{\circ} \mathrm{C}$ & Temperature \\
\hline GluInj & $\mathrm{mmol}{ }^{13} \mathrm{C} \mathrm{m}^{-2} \mathrm{~d}^{-1}$ & Flux of injected ${ }^{13} \mathrm{C}$-labeled glucose \\
\hline POCinput & $\mathrm{mmol} \mathrm{C} \mathrm{m} \mathrm{m}^{-2} \mathrm{~d}^{-1}$ & POC input \\
\hline
\end{tabular}

TOC pool. Bacteria quickly acquired ${ }^{13} \mathrm{C}$ label following the ${ }^{13} \mathrm{C}$-glucose injection (Fig. 2B), although label incorporation was somewhat variable among the plots. In particular, peak labeling was higher in plot 2 than in plot 1 (7.2 [day 8] versus 3.5 [day 6] $\mathrm{mmol}^{13} \mathrm{C} \mathrm{m}^{-2}$ ). Before and after the peak labeling, excess ${ }^{13} \mathrm{C}$ in bacteria was similar for both plots. Label incorporation was linear over the first $8 \mathrm{~d}$ at a rate of $0.62 \mathrm{mmol}^{13} \mathrm{C} \mathrm{m}^{-2} \mathrm{~d}^{-1}$, after which the excess ${ }^{13} \mathrm{C}$ decreased in an exponential fashion (Fig. 2B). Meiobenthic label incorporation was swift and peaked around day 10 at $0.07 \mathrm{mmol}^{13} \mathrm{C} \mathrm{m}^{-2}$, representing $0.02 \%$ of the label in ${ }^{13} \mathrm{C}$-TOC. The label decreased exponentially and returned to background levels at the end of the experiment (Fig. 2C). Labeling of macrobenthos was comparatively similar among both plots, although the plot with highest bacterial labeling also had the highest macrobenthic labeling (Fig. 2D). Macrobenthic labeling was rapid during the first $10 \mathrm{~d}$ and reached an average $0.78 \mathrm{mmol}{ }^{13} \mathrm{C} \mathrm{m}^{-2}$ at day 5 . The labeling variability at days 5-10 was, among others, caused by variable labeling of the biomass dominating large $M$. balthica (species data not shown). Label decreased exponentially with time, and after 4.5 months, $0.1 \mathrm{mmol}^{13} \mathrm{C} \mathrm{m}^{-2}$ resided in macrobenthos (Fig. 2D). The injected ${ }^{13} \mathrm{C}$-glucose was rapidly respired to ${ }^{13} \mathrm{C}$-DIC, as evidenced by the $0.46 \mathrm{mmol}^{13} \mathrm{C} \mathrm{m}^{-2}$ respiration in the first $6 \mathrm{~h}$ of the experiment (Fig. 2E). The amount of respired carbon was very similar among the plots, with the plot with highest bacterial labeling showing the highest level of ${ }^{13} \mathrm{C}$ respiration. The respiration rate of ${ }^{13} \mathrm{C}$ label was highest during the injection period, in which an average of $4.7 \mathrm{mmol}^{13} \mathrm{C} \mathrm{m}^{-2}$ was respired. The respiration rate slowed down after the ${ }^{13} \mathrm{C}$-glucose injection and decreased further after day 36, when an average of $7 \mathrm{mmol}^{13} \mathrm{C} \mathrm{m}^{-2}$ had been respired. In the whole experimental period, a total of $8.9 \mathrm{mmol}^{13} \mathrm{C} \mathrm{m}^{-2}$ was respired (Fig. 2E), which corresponds to $15 \%$ of the total ${ }^{13} \mathrm{C}$ addition and about $30 \%$ of label initially present in the TOC pool (Fig. 2A).

The ${ }^{13} \mathrm{C}$ dynamics of the organic carbon pool could be accurately reproduced in the first 2 months, but excess ${ }^{13} \mathrm{C}$ is overestimated by the model at day 136 (Fig. 2A). Modeled bacterial label incorporation tracks the observations from both plots during the first $6 \mathrm{~d}$ of the experiment (Fig. 2B). However, the continued label incorporation in plot 2 , resulting in high peak labeling, was not reproduced. Instead, the model tracks the observations on ${ }^{13} \mathrm{C}$-bacteria from plot 1. This initial underestimation of label incorporation of plot 2 has repercussions for the prediction during the remainder of the experiment. The rate at which label disappears from the bacterial compartment also seems higher in the model than observed in the field. The modelderived bacterial secondary production averaged 66.5 
Table 2. Model parameters. The parameters that only have a mean value were fixed in the simulations. The other parameters are given as mean \pm standard deviation as determined by Bayesian techniques (see Material and methods). The original range was determined from the literature. Abbreviations: meas. is measured and ass. is assumed.

\begin{tabular}{|c|c|c|c|c|c|}
\hline Symbol & Mean value & Range & Unit & Source* & Description \\
\hline Flux $_{G l u}$ & 183 & & $\mathrm{mmol}{ }^{13} \mathrm{C} \mathrm{m}^{-2} \mathrm{~d}^{-1}$ & & Glucose injection rate \\
\hline$Q_{10}$ & 2 & & - & Ass. & Temperature dependence \\
\hline$\varepsilon_{G l u}$ & 0.74 & & - & + & Injection efficiency \\
\hline Flux $_{P O C}$ & 52 & & $\mathrm{mmol} \mathrm{C} \mathrm{m}{ }^{-2} \mathrm{~d}^{-1}$ & 1 & Input of POC \\
\hline$\varepsilon_{M}$ & 0.50 & & - & 2 & Growth efficiency benthos \\
\hline$M e$ & 188 & & $\mathrm{mmol} \mathrm{C} \mathrm{m}{ }^{-2}$ & Meas. & Meiobenthic biomass \\
\hline$M a$ & 1624 & & $\mathrm{mmol} \mathrm{C} \mathrm{m}{ }^{-2}$ & Meas. & Macrobenthic biomass \\
\hline$K_{G l u}$ & $0.34 \pm 0.025$ & $0.29-0.39$ & - & 3 & Glucose adsorption \\
\hline$d_{P, D}$ & $0.0024 \pm 0.00024$ & $0.0005-0.003$ & $\mathrm{~d}^{-1}$ & 4,5 & POC dissolution \\
\hline$\lambda_{P}$ & $0.0085 \pm 0.0024$ & $0.0-0.093$ & $\mathrm{~d}^{-1}$ & 6 & POC exchange \\
\hline$\lambda_{D}$ & $0.58 \pm 0.14$ & $0.05-1.00$ & $\mathrm{~d}^{-1}$ & 7 & DOC exchange \\
\hline$r_{D, B}$ & $0.46 \pm 0.12$ & $0.08-2.67$ & $\mathrm{~d}^{-1}$ & 8 & Bacterial DOC uptake \\
\hline$\varepsilon_{B}$ & $0.50 \pm 0.03$ & $0.40-0.75$ & - & 9 & Bacterial growth efficiency \\
\hline$m_{B}$ & $0.07 \pm 0.02$ & $0.0-0.14$ & $\mathrm{~d}^{-1}$ & 10,11 & Mortality rate \\
\hline$\alpha$ & $0.31 \pm 0.11$ & $0.0-0.50$ & - & Ass. & Metabolic part of biomass \\
\hline$P B_{M e}$ & $0.065 \pm 0.014$ & $0.03-0.09$ & $\mathrm{~d}^{-1}$ & 12 & Meiobenthic production rate \\
\hline$\beta_{M e}$ & $0.097 \pm 0.024$ & $0.05-0.15$ & - & 13 & Bacteria in meiobenthic diet \\
\hline$\rho_{M e}$ & $0.036 \pm 0.012$ & $0.0-0.15$ & - & Ass. & DOC in meiobenthic diet \\
\hline$P B_{M a}$ & $0.028 \pm 0.009$ & $0.01-0.05$ & $\mathrm{~d}^{-1}$ & 12 & Macrobenthic production rate \\
\hline$\beta_{M a}$ & $0.20 \pm 0.05$ & $0.08-0.30$ & - & 13 & Bacteria in macrobenthic diet \\
\hline$\rho_{M a}$ & $0.094 \pm 0.032$ & $0.0-0.15$ & - & Ass. & DOC in macrobenthic diet \\
\hline
\end{tabular}

* Sources are as follows: (1) Widdows et al. (2004), (2) Calow (1977), (3) Henrichs and Sugai (1993), (4) Westrich and Berner (1984), (5) Henrichs and Doyle (1986), (6) Widdows et al. (2000), (7) Schluter et al. (2000), (8) Arnosti and Holmer (1999), (9) del Giorgio and Cole (1998), (10) Fischer et al. (2003), (11) Mei and Danovaro (2004), (12) Heip et al. (1995) and references therein, and (13) Van Oevelen et al. (unpubl. data).

+ Defined as the amount of label recovered after the first $4 \mathrm{~h}$.

mmol C m-2 $\mathrm{d}^{-1}$ and bacterial growth efficiency $(B G E)$ was calibrated at $0.50 \pm 0.03$ (Table 2). Meiobenthic and macrobenthic labeling are accurately described, the modeled magnitude of labeling and label dynamics correspond well to the field observations (Fig. 2C,D). Secondary production derived from the model for meiobenthos and macrobenthos averaged $11.5 \mathrm{mmol} \mathrm{C} \mathrm{m} \mathrm{C}^{-2} \mathrm{~d}^{-1}$ and $42.5 \mathrm{mmol} \mathrm{C} \mathrm{m}^{-2} \mathrm{~d}^{-1}$, respectively. Respiration of ${ }^{13} \mathrm{C}$ label is very well described during the first 3 months, but the model underestimates the respiration slightly thereafter (Fig. 2E). Overall, the model predictions versus field observations, covering data over four orders of magnitude, reveal a highly significant linear relation with a slope that was very close to one (Fig. 3).

Some model parameters were more constrained by the observations than others (Table 2). The standard deviation relative to the mean was $\leq 10 \%$ for the parameters bacterial growth efficiency $\left(\varepsilon_{B}\right)$, glucose adsorption $\left(K_{G l u}\right)$, and POC dissolution rate $\left(d_{P, D}\right)$ and between $24-37 \%$ for the other parameters, which was similar to the relative standard deviation of the observations. Although many parameters have a high relative standard deviation, they were well constrained with regard to their initial range. The parameters POC dissolution rate $\left(d_{P, D}\right)$, POC exchange rate $\left(\lambda_{P}\right)$, bacterial DOC uptake rate $\left(r_{D, B}\right)$, bacterial mortality $\left(m_{B}\right)$, fraction DOC in meiobenthic diet $\left(\rho_{M e}\right)$, and macrobenthic production rate $\left(P B_{M a}\right)$ were well constrained as compared with their initial range. However, the standard deviations for the parameters $\alpha$ (metabolic fraction of benthos), $\beta_{M e}$ (bacterial fraction in meiobenthic diet), $P B_{M e}$ (production rate meiobenthos), $\rho_{M a}$ (DOC fraction in macrobenthic diet), and $K_{G l u}$ (glucose adsorption constant) are still high as compared with the initial ranges, and these parameters were less constrained by the observations.

Label pathways - The use of a mechanistic model not only allowed us to reproduce the observations and derive useful model parameters, but also to provide detailed information on the relative contributions of the different ${ }^{13} \mathrm{C}$ pathways (Fig. 4). The importance of the ${ }^{13} \mathrm{C}$ loss pathways from the sediment changed considerably with time. Initially, label loss occurred mainly through exchange of DOC $(75 \%)$ and respiration (20\%), but after a few days, POC exchange dominated (Fig. 4A). Meiobenthic and macrobenthic turnover accounted for maximal $10 \%$ of the label loss. The fate of bacterial carbon production was rather invariant during the experiment and was partitioned among exchange $(8 \%)$, meiobenthic grazing (3\%), macrobenthos grazing (24\%), and mortality (65\%) (Fig. 4B). The label sources for macrobenthos (very similar for meiobenthos) reflect the different turnover rates of DOC and bacteria. During the first 5-d period of label addition, $75 \%$ of label incorporation was by meiobenthos and macrobenthos and was related to the uptake of DOC, but within 2 days of ending the label injections, bacterivory dominated label incorporation (90\%) and remained high thereafter (Fig. 4C).

\section{Discussion}

This is the first study to consider both the short-term and long-term fates of benthic bacterial carbon production (BP) using a combination of in situ observations and a mecha- 
Table 3. Model equations. The miscellaneous symbol $X$ is specified for every state variable or variable. The symbol $M x$ stands for both $M e$ and $M a$.

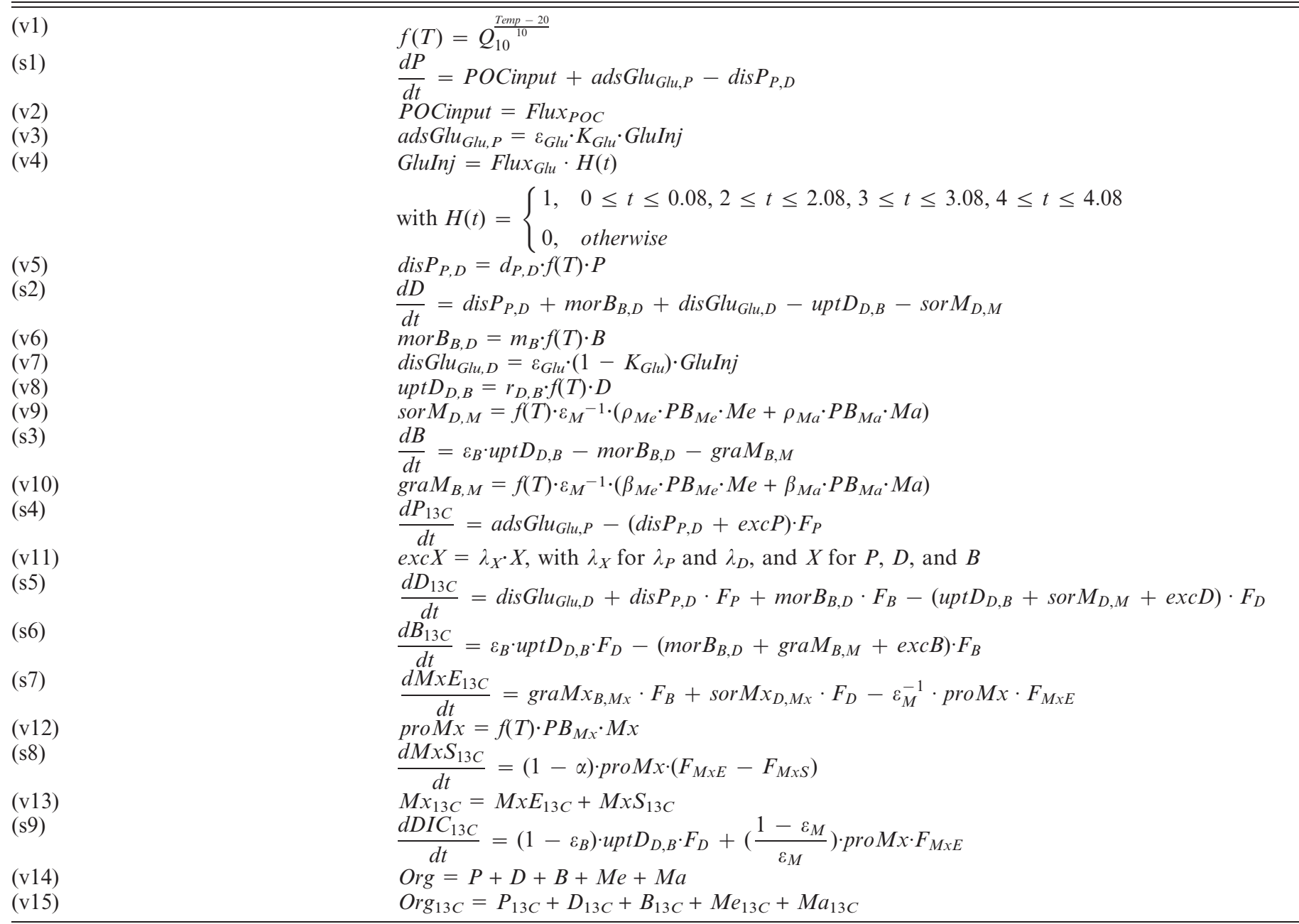

nistic model. The sediment was labeled with ${ }^{13} \mathrm{C}$-glucose on several consecutive days to ensure sufficient labeling of the bacteria and to follow uptake kinetics of ${ }^{13} \mathrm{C}$ in several biotic and abiotic compartments. Subsequently, label appearance and retention was monitored over a period of 4.5 months to provide information on transfer between and turnover of the different compartments. In reiteration, the full data set comprises regular sampling during 4.5 months of bacterial carbon, total organic carbon, bacterial ${ }^{13} \mathrm{C}$, meiobenthic ${ }^{13} \mathrm{C}$, macrobenthic ${ }^{13} \mathrm{C}$, and respiration of ${ }^{13} \mathrm{C}$ to dissolved inorganic carbon. In addition, total meiobenthic biomass (sum of meiobenthic groups) and total macrobenthic biomass (sum of macrobenthic species) were available from several sampling cores (meiobenthos) and one dedicated sampling with 12 cores outside the experimental plots (macrobenthos). This data set was evaluated by means of a mechanistic model, in which we parameterized the gain and loss processes of total $\mathrm{C}$ and ${ }^{13} \mathrm{C}$ of particulate organic carbon, dissolved organic carbon, bacteria, and ${ }^{13} \mathrm{C}$ of meiobenthos and macrobenthos (Fig. 1 and Tables 1-3). In a calibration procedure, the governing model parameters were adjusted such that the model output reproduced the observed data as closely as possible (Fig. 2). The model output with the optimal parameter values was used to deduce the magnitude of the different gain and loss processes (e.g., bacterial production, bacterivory by meiobenthos and macrobenthos, bacterial mortality, and respiration by the biotic compartments).

Our mechanistic model required an explicit description of its structure, underlying assumptions, and contains interpretable parameters. Simpler models could have been used, but these only use a subset of the available data. For example, label disappearance can be fitted with an exponential decay model to obtain the turnover rates of the compartments. However, in such a simple analysis, data on uptake kinetics are ignored, rate constants represent net turnover as uptake of label continues after label injection, and the model fit is not constrained by any of the other observations. Moreover, the use of a mechanistic model allowed us to derive information on parameter values and unmeasured processes, on which we focus later in the discussion.

Inherent in benthic microbial ecology are methodological shortcomings, and our experimental approach is no exception. These are partly caused by our intention to 
Table 4. Biomass of bacteria, meiobenthos, and macrobenthos in $\mathrm{mmol} \mathrm{C} \mathrm{m}^{-2}$.

\begin{tabular}{lc}
\hline \hline \multicolumn{1}{c}{ Compartment } & Biomass \\
\hline Bacteria & 781 \\
Meiobenthos & 188 \\
Nematoda & 67 \\
Hard-shelled Foraminifera & 62 \\
Juvenile Heteromastus filiformis & 34 \\
Unknown & 9 \\
Soft-bodied Foraminifera & 6 \\
Turbellaria & 4 \\
Small Polychaeta & 4 \\
Copepoda & 3 \\
Macrobenthos & 1,624 \\
Macoma balthica $(>7$ mm) & 671 \\
Heteromastus filiformis & 597 \\
Pygospio elegans & 215 \\
Polydora cornuta & 34 \\
Macoma balthica $(\leq 7$ mm) & 28 \\
Hydrobia ulvae & 24 \\
Nereis spp. & 21 \\
Eteone sp. & 16 \\
Corophium spp. & 16 \\
Streblospio benedicti & 1 \\
\hline
\end{tabular}

conduct the experiment over a long time scale in situ, which precludes core incubations. Label was introduced in injection wells at high resolution, but heterogeneous label distribution in the sediment is inevitable. However, it is the preferred method to introduce label while minimizing sediment disturbance (Dobbs et al. 1989). Label uptake by nongrazing processes has been reported by Carman (1990), which may complicate the interpretation of the ${ }^{13} \mathrm{C}$ data in terms of grazing. However, turnover time of glucose (hours) is much shorter than that of bacteria (days), which allowed a distinction between direct uptake of glucose and bacterial grazing at the time scale of the experiment. Another concern was the potential use of respired ${ }^{13} \mathrm{C}$ by microphytobenthos. Fixation of ${ }^{13} \mathrm{C}$-DIC enriches microphytobenthos into an alternative ${ }^{13} \mathrm{C}$ resource, thus complicating the interpretation of carbon transfer from bacteria to meiobenthos and macrobenthos. Microphytobenthic labeling was assessed through the PLFA biomarker C20:5 03 (Middelburg et al. 2000), which increased in $\delta^{13} \mathrm{C}$ from $-22.8 \%$ to $19.8 \%$ o (day 8 ) and remained above $5.0 \%$ until day 23. This labeling is lower than the $\delta^{13} \mathrm{C}$ of most grazers (Van Oevelen et al., unpubl. data) and much lower than the $\delta^{13} \mathrm{C}$ of bacterial biomarkers (between $100 \%$ and $500 \%$ during the first month). Hence, recycling of ${ }^{13} \mathrm{C}$ via microphytobenthos does not seriously complicate the interpretation. Finally, glucose addition was truly at tracer level, as the rate of label incorporation $\left(0.62 \mathrm{mmol}{ }^{13} \mathrm{C}\right.$ $\mathrm{m}^{-2} \mathrm{~d}^{-1}$ ) represented $0.9 \%$ of the total bacterial production $\left(66.5 \mathrm{mmol} \mathrm{C} \mathrm{m}^{-2} \mathrm{~d}^{-1}\right)$.

Model complexity and performance-Model complexity was a compromise between biological realism and data availability. The zero-dimension representation was one

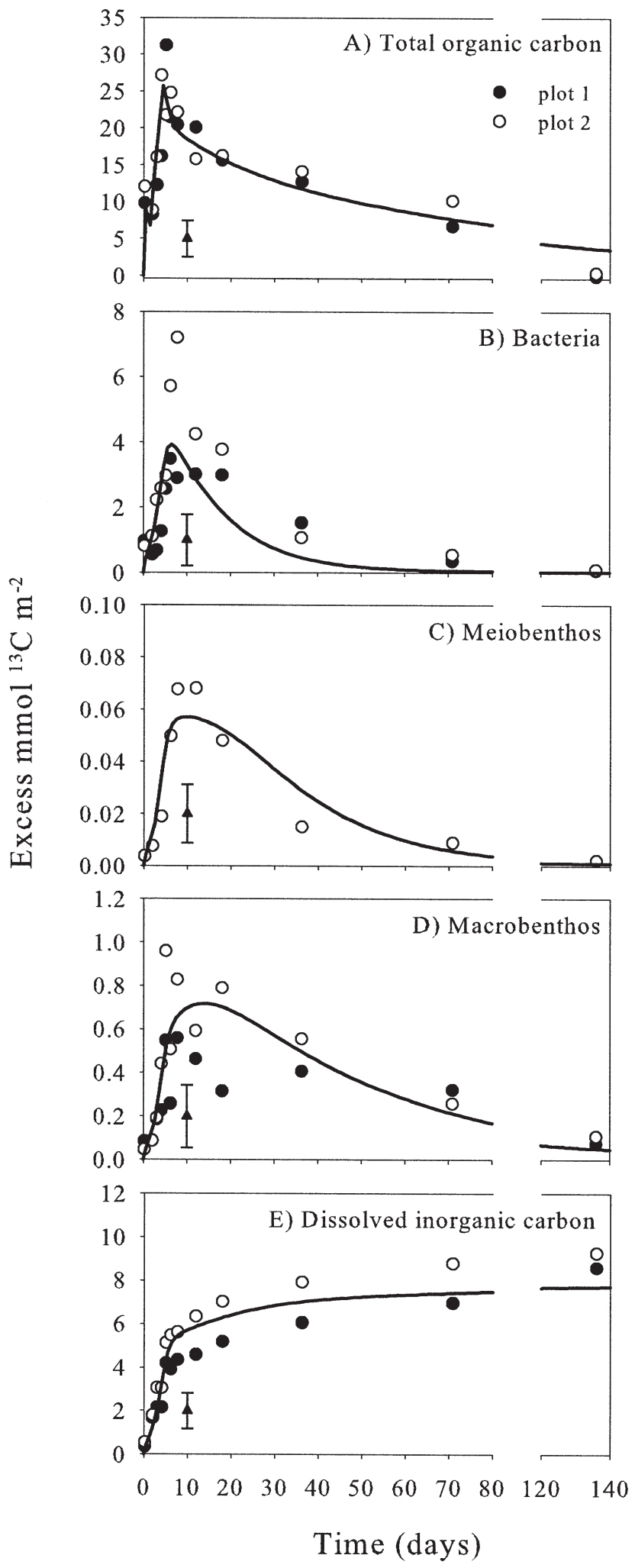

Fig. 2. Excess $\mathrm{mmol}{ }^{13} \mathrm{C} \mathrm{m}^{-2}$ in both plots and modelderived lines of the compartments (A) total organic carbon, (B) bacteria, (C) meiobenthos, (D) macrobenthos, and (E) dissolved inorganic carbon (accumulated in time). Error bars in the plot are the average standard deviations used in the calibration routine (see Material and methods). Note the scale break in the time axis. 


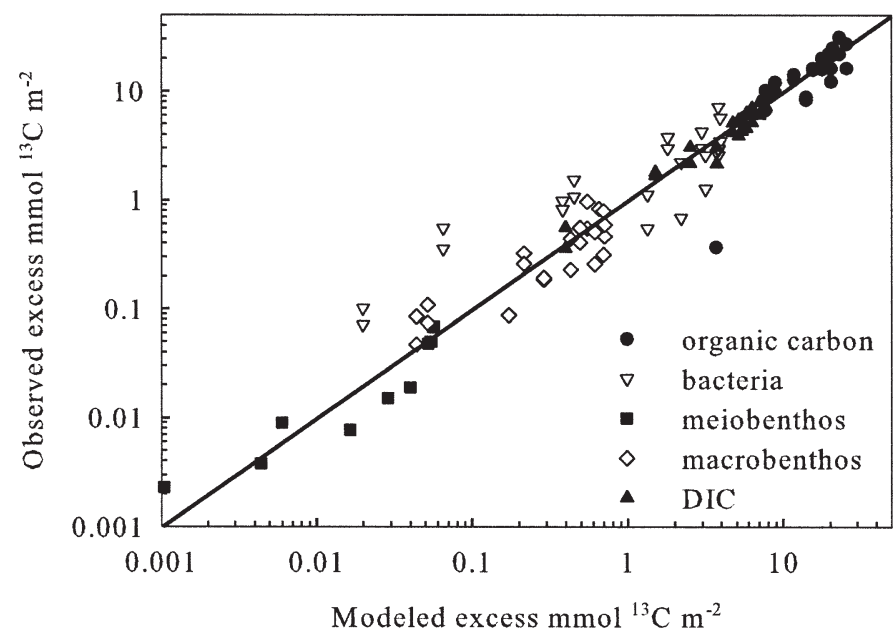

Fig. 3. Modeled versus observed values of both plots of excess mmol ${ }^{13} \mathrm{C} \mathrm{m}^{-2}$ in the model compartments. DIC is dissolved inorganic carbon. The solid line represents the linear regression of all data points $\left(y=0.97 x, r^{2}=0.91, p<0.0001, n=106\right)$.

way to minimize model complexity. Among the depth intervals, there were minor and quasirandom differences in bacterial and organic carbon $\delta^{13} \mathrm{C}$. Therefore, the information gain of a one-dimensional representation would not outweigh the necessary additional model parameters. Moreover, a one-dimensional model description in terms of biomass, feeding, and mixing of meiobenthos and macrobenthos is not straightforward.

Sediment organic carbon is characterized by large differences in reactivity (Westrich and Berner 1984). In the model, two pools with different lability were distinguished: labile DOC and less reactive POC. This distinction is required as glucose is very labile compared with bulk sediment organic carbon. The turnover rate for the DOC pool is somewhere between the very fast turnover of injected glucose and slower turnover of DOC that is derived from bacteria or POC. However, data on $\mathrm{C}$ and ${ }^{13} \mathrm{C}$ were only available for total organic carbon and more complexity than two organic carbon pools could therefore not be justified.

Bacterial biomass varied considerably and was generally between 500 and $1,300 \mathrm{mmol} \mathrm{C} \mathrm{m}^{-2}$. The bacterial biomass in the model was fitted to a constant overall average (781 $\mathrm{mmol} \mathrm{C} \mathrm{m}^{-2}$ ), and the model output therefore showed little variation (600-800 $\left.\mathrm{mmol} \mathrm{C} \mathrm{m}^{-2}\right)$. There were several reasons for this approach. There was hourly/daily variation and a more seasonal-like trend on the scale of weeks/months. Short-term variation of a factor $2-3$ is inherent in many bacterial biomass estimates and likely contains an important spatial component. This variation cannot be reproduced using the first-order zero-dimensional model that is designed to reproduce excess ${ }^{13} \mathrm{C}$ patterns. The long-term variation shows a general increase in biomass during the first 2-3 weeks of the experiment and then a decrease (data not shown). Temperature dependence alone cannot explain the biomass evolution because temperature increased during the initial 3 months. We ran simulations with a higher bacterial biomass $(1,000 \mathrm{mmol}$ $\mathrm{C} \mathrm{m}^{-2}$ ) than the season average, which improved the fit of
A) Loss of ${ }^{13} \mathrm{C}$ label from the sediment

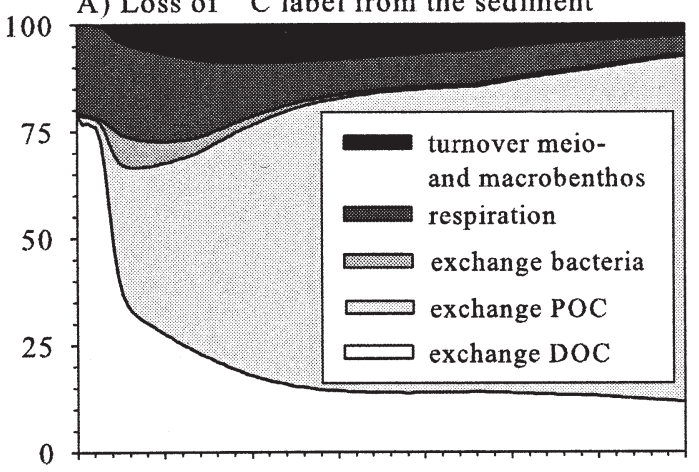

B) Fate of bacterial ${ }^{13} \mathrm{C}$ production

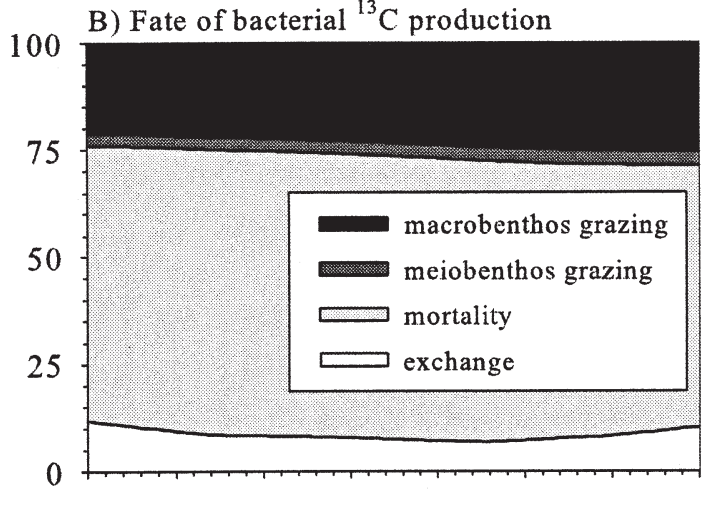

C) Macrobenthic ${ }^{13} \mathrm{C}$ sources

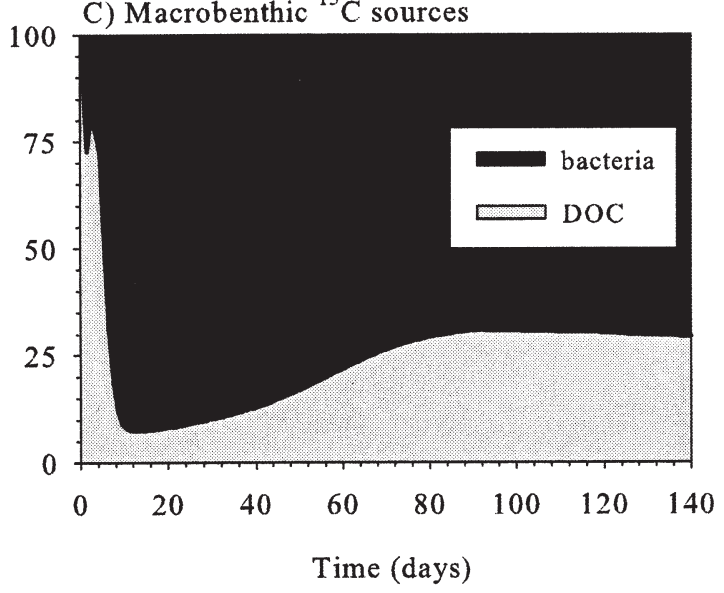

Fig. 4. Percentage contribution of excess ${ }^{13} \mathrm{C}$ pathways in (A) loss of ${ }^{13} \mathrm{C}$ from the sediment, (B) fate of bacterial ${ }^{13} \mathrm{C}$ production, and $(\mathrm{C})$ macrobenthic ${ }^{13} \mathrm{C}$ sources.

excess ${ }^{13} \mathrm{C}$ in bacteria but did not change the general conclusions as presented here.

Bacterial biomass is modeled as a homogeneous pool that experiences growth and loss processes. However, it has been reported that the benthic bacterial community consists of a small pool of actively growing bacteria and a dominant pool of nongrowing dormant bacteria (Novitsky 1987). Hence, one can envision two end members, one with intense exchanges between active and dormant bacteria, in which bacterial biomass acts as one homogeneous pool, and one with no exchanges, in which the active and dormant pools act as two uncoupled pools of bacterial 
biomass. When both pools are equally susceptible to bacterial loss processes (e.g., viral lysis, grazing), active exchange from the active to the dormant pool is required to maintain a dominance of the dormant pool. However, when dormant bacteria are less susceptible to loss processes, lower exchanges suffice to maintain the dominance of dormant bacteria. What are the implications for the interpretation of the ${ }^{13} \mathrm{C}$-glucose labeling experiment? If significant parts of the active and dormant pools exchange on a time scale of minutes to days, the labeling period of 5 $\mathrm{d}$ is sufficient to label most of the active and dormant pool of bacterial biomass, and our model implementation is justified. However, when exchanges between the active and dormant pools occur on longer time scales, only the small pool of actively growing bacteria was labeled, and our model of bacterial biomass may be biased. To explore this potential bias, the model was fitted to the data with bacterial biomass lowered to $15 \%$, i.e. $117 \mathrm{mmol} \mathrm{C} \mathrm{m}^{-2}$, assuming that bacterial dynamics were accounted for by a small pool of actively growing bacteria. The fit to the data was slightly worse for excess ${ }^{13} \mathrm{C}$ in total organic carbon, meiobenthos, macrobenthos, and dissolved inorganic carbon. However, the fit with the lowered bacterial biomass was much worse for excess ${ }^{13} \mathrm{C}$ in bacteria, with peak labeling of $2.17 \mathrm{mmol}^{13} \mathrm{C} \mathrm{m}^{-2}$ at day 6 and $0.12 \mathrm{mmol}{ }^{13} \mathrm{C}$ $\mathrm{m}^{-2}$ at day 20, as compared with 3.94 and $1.55 \mathrm{mmol}$ ${ }^{13} \mathrm{C} \mathrm{m}^{-2}$ in the fit with total bacterial biomass (Fig. 2A). The bacterial mortality rate $\left(m_{B}\right)$ was much higher in the low biomass fit $\left(0.14\right.$ vs. $\left.0.07 \mathrm{~d}^{-1}\right)$. Dependencies of meiobenthos $\left(\beta_{M e}\right)$ and macrobenthos $\left(\beta_{M a}\right)$ on bacteria were very similar, but because bacterial production is lower in the low biomass fit, the relative importance of grazing as a fate of bacterial production increased to a similar level as mortality. Because exchange rates between the active and dormant fractions are unknown, we simplified our model and described bacteria as one pool that experiences similar growth and loss processes, but note that this simplification also applies in the case of high exchanges between the active and dormant bacteria pools.

Plante et al. (1989) identified the hindgut of deposit feeders as a hot spot of bacterial production. Our model is not spatially explicit, and consequently, the modeled bacterial production is therefore averaged over the entire $10-\mathrm{cm}$ sediment column. Hence, it includes not only sites in the sediment with very low bacterial production, but also hot spots of production in nutritious sites in the sediment or in the hindgut of deposit feeders.

The faunal biomass was modeled as two compartments: a metabolic and a structural compartment (s7 and s8 in Table 3). Turnover is higher in the metabolic pool, as this pool fuels respiration. This formulation was chosen for its higher realism (Conover 1961), success in earlier applications (Lehman et al. 2001), and improved capability of reproducing the observations. The steady-state assumption for meiobenthos and macrobenthos was a required simplification because we were not able to model the dynamics of other food sources nor did we have sufficient data to evaluate the dynamics of the meiobenthos and macrobenthos dynamics over time. We did not include potential macrobenthic grazing on meiobenthos in our model for simplicity. However, the results are not likely to be influenced by this assumption for several reasons. First, the amount of ${ }^{13} \mathrm{C}$ in meiobenthos is much lower than that in macrobenthos (Fig. 2C,D); therefore, meiobenthos could not have been an important source of ${ }^{13} \mathrm{C}$. Second, meiobenthic production is only $27 \%$ of macrobenthic production and can therefore not be an important carbon source. Finally, $\delta^{13} \mathrm{C}$ labeling of macrobenthos specimens was frequently higher than that of meiobenthos, indicating that other labeled carbon sources were more important for macrobenthos (Van Oevelen et al., unpubl. data).

Finally, the level of variability in excess ${ }^{13} \mathrm{C}$ encountered in this study, especially for bacteria (Fig. 2B), is not uncommon for this type of in situ labeling studies (see e.g., Hall and Meyer 1998; Middelburg et al. 2000). Moreover, we thoroughly tested different data-weighting schemes and model scenarios to assess the robustness of the model results. Model scenarios with no contribution of DOC to carbon uptake by meiobenthos and macrobenthos, i.e., $\rho_{M e}=0$ and $\rho_{M a}=0$, typically show a lag in labeling, delayed peak labeling, and higher loss rate as compared with the observations. Thus, the model results are robust and accurately describe the general trends in the labeling patterns.

Bacterial growth efficiency and production-The parameter $B G E$ was calibrated at $0.50 \pm 0.03$. The calibration of $B G E$ is based on respiration of relatively labile compounds (initially ${ }^{13} \mathrm{C}$-glucose and later bacterially derived DOC). Therefore, the calibrated $B G E$ might be an overestimate of the overall community $B G E$ because degradation of less labile organic matter in intertidal sediment likely results in a lower $B G E$ of the community. Indeed, our $B G E$ lies at the upper end of particulate organic substrates, but is comparable with labile extracellular organic carbon (del Giorgio and Cole 1998). To test what the effect of a lower $B G E$, e.g. because of anaerobic conditions, would be on our conclusions regarding the fate of bacterial carbon production, we ran a calibration with the $B G E$ fixed to 0.20 (data on ${ }^{13} \mathrm{C}$-DIC were omitted from the calibration). The other parameters were either fixed or calibrated from their initial range as specified in Table 2. The model fit of most observations compared readily with the fits given here (Fig. 2), although the fit of ${ }^{13} \mathrm{C}-\mathrm{TOC}$ was somewhat worse in the low $B G E$ scenario. The main difference with the high $B G E$ scenario was that the uptake rate of DOC by bacteria was higher $\left(2.4 \mathrm{~d}^{-1}\right.$ vs. $\left.0.46 \mathrm{~d}^{-1}\right)$, which resulted in a lower DOC concentration (results not shown). The latter implies that the ${ }^{13} \mathrm{C}$-glucose injection gives much higher $\delta^{13} \mathrm{C}$-DOC values, and therefore labeling of bacteria is very similar, although bacteria respired more ${ }^{13} \mathrm{C}$. Due to the higher bacterial respiration, bacterial production is lower $\left(21 \mathrm{mmol} \mathrm{C} \mathrm{m} \mathrm{C}^{-2} \mathrm{~d}^{-1}\right)$ in the low $B G E$ scenario. Importantly, however, the conclusions with respect to the fate of bacterial carbon in terms of mortality, grazing by meiobenthos, and grazing by macrobenthos in simulations based on a low $B G E$ are very comparable with those presented here (Fig. 4).

The bacterial dominance of benthic secondary production has been reported earlier (e.g., Schwinghamer et al. 1986) and is confirmed in this study with bacteria 
accounting for $55 \%$ of the secondary production. The regression models presented by Sander and Kalff (1993) predict bacterial production $\left(66.5 \mathrm{mmol} \mathrm{C} \mathrm{m} \mathrm{m}^{-2} \mathrm{~d}^{-1}\right)$ reasonably when based on bacterial carbon $(91 \mathrm{mmol} \mathrm{C}$ $\left.\mathrm{m}^{-2} \mathrm{~d}^{-1}\right)$ or POC $\left(42 \mathrm{mmol} \mathrm{C} \mathrm{m} \mathrm{C}^{-2} \mathrm{~d}^{-1}\right)$, but their temperature model $\left(15 \mathrm{mmol} \mathrm{C} \mathrm{m} \mathrm{C}^{-2} \mathrm{~d}^{-1}\right)$ underestimates our bacterial production.

Boudreau (1999) presented detailed mass balances of bacterial carbon in sediments and scaled the mass balance terms to derive a linear relation between bacteria and POC. The parameters of this linear relation are composed of parameters for irrigation, advection, bacterial production, mortality, grazing, and bacterial growth efficiency. When the parameters obtained in our study are implemented in Boudreau's scaled linear model, the predicted ratio between bacterial biomass and POC is 0.005 , consistent with, but at the lower end of the observed ratios, ranging from 0.005 to 0.024 . The predicted bacterial biomass-to-POC ratio is based on interpretative and measurable parameters rather than regression parameters. The general agreement is certainly encouraging, but additional data sets from other types of sediment are required to test the general predictive power.

Fate of bacterial carbon production-The microbial loop has been formalized as bacterial assimilation of dissolved organic matter and subsequent transfer up the food web by bacterivory and predation on bacterivores (Azam et al. 1983). The significance and efficiency of this loop has focused on a link or sink debate: Is bacterial production a carbon link or sink in the food web? The intractable benthic environment has made experimental studies difficult and studies therefore have tended to focus on a subset of potential grazers, such as heterotrophic flagellates (Hamels et al. 2001), meiobenthos (Montagna 1993), or macrobenthic species (Kemp 1987). These studies revealed that $1-20 \%$ of the bacterial production is grazed. This generalization is restricted to coastal and intertidal sediments and may not hold for deep-sea sediments due to the limited availability of nitrogen resources (Jumars et al. 1990). For the present study site, we estimate that $30 \%$ of the bacterial production was grazed, $1-2 \%$ by microbenthos $\left(1.1 \mathrm{mmol} \mathrm{C} \mathrm{m} \mathrm{C}^{-2} \mathrm{~d}^{-1}\right.$, from Hamels et al. 2001), 3\% by meiobenthos (this study), and $24 \%$ by macrobenthos (this study). As meiobenthic and macrobenthic biomass at our study sites are high as compared with other coastal and intertidal sediments (Heip et al. 1995), we assert that bacterivory is comparatively intense at our study site. Given the accumulated evidence, grazing can be regarded as a minor to moderate fate of bacterial production in intertidal sediments.

Our combined experimental and modeling approach allowed us to disentangle the bacterial loss pathways of grazing, exchange, and mortality. Bacterial mortality appeared to dominate and represented a sink of $65 \%$ of the bacterial production. However, the cause of bacterial mortality remains unexplained. Several mortality causes are known. Bacterial cell lysis resulting from lytic infection by viruses is a major cause of bacterial mortality in pelagic systems (Fuhrman 2000) and was thought to be even more important in sediments because of higher viral and bacterial abundances (Paul et al. 1993; Mei and Danovaro
2004). Recent estimates on the contribution of viral lysis in bacterial mortality show a large range of $0-40 \%$ (Fischer et al. 2003; Mei and Danovaro 2004). Therefore, viral lysis may be an important cause of bacterial mortality, but large differences in reported contributions hinder generalization of the importance of this process. Programmed cell death, i.e., mortality caused by triggering an intracellular genetic code, has been found in bacterial cultures (Yarmolinsky 1995), but remains to be quantified for natural bacterial populations. Similarly, environmental factors, such as the presence of toxic compounds and thermal or salinity stress, may cause mortality, but also their quantitative importance remains unknown. Several factors causing bacterial mortality, other than grazing, are not yet or only recently being explored, and their importance remains to be established. Irrespective of the cause of death, nongrazing mortality results in the release of bacterially derived carbon that is potentially available for recycling back to DOC.

Recycling in the DOC-bacteria loop was evaluated by a recycling efficiency, defined as $E=$ (bacterial death)/ (bacterial DOC uptake), and the average number of cycles in the loop of a carbon molecule as $R=$ (bacterial death/POC dissolution + DOC exchange), both based on seasonaveraged flow values. The recycling efficiency may vary between 0 (no recycling) and 1 (full recycling) and $R$ between 0 (molecule cycles zero times) and $\infty$ (molecule cycles infinitely). The recycling efficiency for the DOC-bacterial loop was moderate (0.36). Note that respiration losses cap $E$ to a maximum of 0.50 (i.e., $\varepsilon_{B}=0.50$, Table 2), which implies that $72 \%$ (i.e., $0.36 / 0.50$ ) of the bacterial production is recycled back to the DOC pool. Despite moderate recycling, $R$ was comparatively low $(0.17)$ due to the high exchange rate of DOC that dominates over the flux from bacteria to DOC. Recycling of bacterially derived carbon is consistent with observations that bacterial lysate is readily degraded by natural communities (Novitsky 1986; Middelboe et al. 2003). However, several studies document the accumulation of the bacterial cell wall-derived D-alanine in oceanic water (McCarthy et al. 1998) and continental margin sediments (Grutters et al. 2002). In a companion paper (Veuger et al., in press), the ${ }^{13} \mathrm{C}$ in D-alanine and other amino acids is compared with that in labile PLFA, and the results suggest that burial of bacterial remnants is not a major sink for bacterial carbon. This suggests that the majority of bacterially derived organic carbon does not build up in the POC pool, but is instead recycled back to the labile DOC pool and is subsequently degraded.

Alongi (1994) speculated on the role of bacterial cycling in tropical coastal sediments and asserted that the majority of bacterial production remains ungrazed but instead lyses, and the lysate is recycled within the bacterial community. A bacterial-viral loop was recently also proposed for pelagic food webs (Fuhrman 2000). Our study on the fate of benthic bacterial carbon production supports this concept, although the cause of death may not necessarily be viral lysis. The observed recycling is also consistent with the well-documented efficient recycling of ammonium in sediments with net rates of regeneration being a fraction of gross ammonification (Blackburn and Henriksen 1983). However, the vast majority of studies on the fate of 
bacterial production (including this study) is conducted in intertidal or shallow sediments, where labile carbon and nitrogen sources are abundantly available. Whether our observations regarding the fate of bacterial carbon also apply to other benthic systems is still an open question. In deep-sea sediments that receive low and pulsed inputs, carbon and especially nitrogen limitation forces subsurface deposit feeders to rely on bacteria for an important part of their nutrition (Jumars et al. 1990). Similarly, in a freshwater stream habitat that is fueled predominantly by refractory leaf litter input, many invertebrates derive $>50 \%$ of their carbon from bacteria (Hall and Meyer 1998).

Finally, the advent of diagenetic models that explicitly include bacterial biomass (Talin et al. 2003) requires an appropriate parameterization of benthic bacterial dynamics. The correspondence between the mass-balance model developed by Boudreau (1999) and our results suggests a promising avenue for further exploration.

\section{References}

Alongi, D. M. 1994. The role of bacteria in nutrient recycling in tropical mangrove and other coastal benthic ecosystems. Hydrobiologia 285: 19-32.

Arnosti, C., AND M. Holmer. 1999. Carbohydrate dynamics and contributions to the carbon budget of an organic-rich coastal sediment. Geochim. Cosmochim. Acta 63: 393-403.

Azam, F., T. Fenchel, J. G. Field, J. S. Gray, L. A. Meyer-Reil, And F. Thingstad. 1983. The ecological role of water-column microbes in the sea. Mar. Ecol. Prog. Ser. 10: 257-263.

Bird, D. F., And C. M. Duarte. 1989. Bacteria organic-matter relationship in sediments - a case of spurious correlation. Can. J. Fish. Aquat. Sci. 46: 904-908.

Blackburn, T. H., and K. Henriksen. 1983. Nitrogen cycling in different types of sediments from Danish waters. Limnol. Oceanogr. 28: 477-493.

Boudreau, B. P. 1999. A theoretical investigation of the organic carbon-microbial biomass relation in muddy sediments. Aquat. Microb. Ecol. 17: 181-189.

Calow, P. 1977. Conversion efficiencies in heterotrophic organisms. Biol. Rev. 52: 385-409.

CARman, K. R. 1990. Mechanisms of uptake of radioactive labels by meiobenthic copepods during grazing experiments. Mar. Ecol. Prog. Ser. 68: 71-83.

Conover, R. J. 1961. The turnover of phosphorus by Calanus finmarchicus. J. Mar. Biol. Assoc. UK 41: 484488.

DEL Giorgio. P. A., AND J. J. Cole. 1998. Bacterial growth efficiency in natural aquatic systems. Annu. Rev. Ecol. Syst. 29: 503-541.

Dobbs, F. C., J. B. Guckert, and K. R. Carman. 1989. Comparison of 3 techniques for administering radiolabeled substrates to sediments for trophic studies - incorporation by microbes. Microb. Ecol. 17: 237-250.

Epstein, S. S., AND M. P. Shiaris. 1992. Rates of microbenthic and meiobenthic bacterivory in a temperate muddy tidal flat community. Appl. Environ. Microbiol. 58: 2426-2431.

Fenchel, T., G. M. King, and T. H. Blackburn. 1998. Bacterial biogeochemistry. The ecophysiology of mineral cycling. Academic Press.

Fischer, U. R., C. Wieltschnig, A. K. T. Kirschner, and B. Velimirov. 2003. Does virus-induced lysis contribute significantly to bacterial mortality in the oxygenated sediment layer of shallow oxbow lakes? Appl. Environ. Microbiol. 69: $5281-5289$.
Fuhrman, J. 2000. Impact of viruses on bacterial processes, p. 327-350. In D. L. Kirchman [ed.], Microbial ecology of the oceans. Wiley-Liss.

Gelman, A., J. B. Carlin, H. S. Stern, and D. B. Rubin. 2003. Bayesian data analysis. Texts in statistical science series. Chapman and Hall/CRC.

Grutters, M., W. van RaAphorst, E. Epping, W. Helder, J. W. De Leeuw, D. P. Glavin, And J. Bada. 2002. Preservation of amino acids from in situ-produced bacterial cell wall peptidoglycans in northeastern Atlantic continental margin sediments. Limnol. Oceanogr. 47: 1521-1524.

Hall, R. O., and J. L. Meyer. 1998. The trophic significance of bacteria in a detritus-based stream food web. Ecology 79: 1995-2012.

Hamels, I., K. Muylaert, G. Casteleyn, and W. Vyverman. 2001. Uncoupling of bacterial production and flagellate grazing in aquatic sediments: A case study from an intertidal flat. Aquat. Microb. Ecol. 25: 31-42.

Heip, C. H. R., N. K. Goosen, P. M. J. Herman, J. Kromkamp, J. J. Middelburg, and K. Soetaert. 1995. Production and consumption of biological particles in temperate tidal estuaries. Oceanogr. Mar. Biol. Ann. Rev. 33: 1-149.

Henrichs, S. M., And A. Dovle. 1986. Decomposition of ${ }^{14}$ Clabelled organic substances in marine sediments. Limnol. Oceanogr. 31: 765-778.

, AND S. F. Sugat. 1993. Adsorption of amino-acids and glucose by sediments of Resurrection Bay, Alaska, USAfunctional-group effects. Geochim. Cosmochim. Acta 57: 823-835.

Jumars, P. A., L. M. Mayer, J. W. Deming, J. A. Baross, And R. A. Wheatcroft. 1990. Deep-sea deposit-feeding strategies suggested by environmental and feeding constraints. Philos. Trans. R. Soc. Lond. A Math. Phys. Sci. 331: 85-101.

Kemp, P. F. 1987. Potential impact on bacteria of grazing by a macrofaunal deposit feeder, and the fate of bacterial production. Mar. Ecol. Prog. Ser. 36: 151-161.

1990. The fate of benthic bacterial production. Aquat. Sci. 2: 109-124.

Lehman, J. T., R. Foy, And D. A. Lehman. 2001. Inverse model method for estimating assimilation by aquatic invertebrates. Aquat. Sci. 63: 168-181.

McCarthy, M. D., J. I. Hedges, and R. Benner. 1998. Major bacterial contribution to marine dissolved organic nitrogen. Science 281: 231-234.

Mei, M. L., And R. Danovaro. 2004. Virus production and life strategies in aquatic sediments. Limnol. Oceanogr. 49: 459-470.

Middelboe, M., L. Riemann, G. F. Steward, V. Hansen, and O. Nybroe. 2003. Virus-induced transfer of organic carbon between marine bacteria in a model community. Aquat. Microb. Ecol. 33: 1-10.

Middelburg, J. J., C. Barranguet, H. T. S. Boschker, P. M. J. Herman, T. Moens, and C. H. R. Heip. 2000. The fate of intertidal microphytobenthos: An in situ ${ }^{13} \mathrm{C}$ labeling study. Limnol. Oceanogr. 45: 1224-1234.

Montagna, P. A. 1993. Radioisotope technique to quantify in situ microbivory by meiofauna in sediments, p. 745-753. In P. F. Kemp, B. F. Sherr, E. B. Sherr and J. J. Cole [eds.], Handbook of methods in aquatic microbial ecology. Lewis Publishers.

Moodley, L., H. T. S. Boschker, J. J. Middelburg, P. M. J. Herman, E. De Deckere, and C. H. R. Heip. 2000. The ecological significance of benthic Foraminifera: ${ }^{13} \mathrm{C}$ labelling experiments. Mar. Ecol. Prog. Ser. 202: 289-295.

Novitsky, J. A. 1986. Degradation of dead microbial biomass in a marine sediment. Appl. Environ. Microbiol. 52: 504-509. 
1987. Microbial growth rates and biomass production in a marine sediment: Evidence for a very active but mostly nongrowing community. Appl. Environ. Microbiol. 53: $2368-2372$.

Paul, J. H., J. B. Rose, S. C. Jiang, C. A. Kellogg, and L. Dickson. 1993. Distribution of viral abundance in the reef environment of Key Largo, Florida. Appl. Environ. Microbiol. 59: 718-724.

Plante, C. J., P. A. Jumars, and J. A. Baross. 1989. Rapid bacterial growth in the hindgut of a marine deposit feeder. Microb. Ecol. 18: 29-44.

Price, W. L. 1979. A controlled random search procedure for global optimization. Comput. J. 20: 367-370.

Sander, B. C., AND J. KalfF. 1993. Factors controlling bacterial production in marine and freshwater sediments. Microb. Ecol. 26: 79-99.

SchallenberG, M., And J. KalfF. 1993. The ecology of sediment bacteria in lakes and comparisons with other aquatic ecosystems. Ecology 74: 919-934.

Schluter, M., E. Sauter, H. P. Hansen, and E. Suess. 2000. Seasonal variations of bioirrigation in coastal sediments: Modelling of field data. Geochim. Cosmochim. Acta 64: 821834.

Schmidt, J. L., J. W. Deming, P. A. Jumars, and R. G. Keil. 1998. Constancy of bacterial abundance in surficial marine sediments. Limnol. Oceanogr. 43: 976-982.

Schwinghamer, P., B. Hargrave, D. Peer, and C. M. Hawkins. 1986. Partitioning of production and respiration among size groups of organisms in an intertidal benthic community. Mar. Ecol. Prog. Ser. 31: 131-142.

Soetaert, K., V. deClippele, and P. M. J. Herman. 2002. FEMME, a flexible environment for mathematically modelling the environment. Ecol. Model. 151: 177-193.
Starink, M., I. N. Krylova, M. J. Bargilissen, R. P. M. Bak, and T. E. Cappenberg. 1994. Rates of benthic protozoan grazing on free and attached sediment bacteria measured with fluorescently stained sediment. Appl. Environ. Microbiol. 60: $2259-2264$

Talin, F., C. Tolla, C. Rabouille, and J. C. Poggiale. 2003. Relations between bacterial biomass and carbon cycle in marine sediments: An early diagenetic model. Acta Biotheor. 51: 295-315.

Veuger, B., D. van Oevelen, H. T. S. Boschker, and J. J. Middelburg. In press. Fate of peptidoglycan in an intertidal sediment: An in situ ${ }^{13} \mathrm{C}$-labeling study. Limnol. Oceanogr.

Westrich, J. T., AND R. A. Berner. 1984. The role of sedimentary organic matter in bacterial sulfate reduction: The $\mathrm{G}$ model tested. Limnol. Oceanogr. 29: 236-249.

Widdows, J., A. Blauw, C. H. R. Heip, P. M. J. Herman, C. H. Lucas, J. J. Middelburg, S. Schmidt, M. D. Brinsley, F. Twisk, AND H. Verbeek. 2004. Role of physical and biological processes in sediment dynamics of a tidal flat in Westerschelde Estuary, SW Netherlands. Mar. Ecol. Prog. Ser. 274: 41-56.

-, M. D. Brinsley, P. N. Salkeld, and C. H. Lucas. 2000. Influence of biota on spatial and temporal variation in sediment erodability and material flux on a tidal flat (Westerschelde, The Netherlands). Mar. Ecol. Prog. Ser. 194: 23-37.

Yarmolinsky, M. B. 1995. Programmed cell death in bacterial populations. Science 267: 836-837.

ZoBell, C. E. 1938. Studies on the bacterial flora of marine bottom sediments. J. Sediment. Petrol. 8: 10-18.

Received: 10 March 2005 Accepted: 11 November 2005 Amended: 8 December 2005 